Original Paper http://ajol.info/index.php/ijbcs http://indexmedicus.afro.who.int

\title{
Kinetic and thermodynamic studies adsorption of Methylene Blue (MB) in aqueous solution on a bioadsorbent from Cucumeropsis mannii Naudin waste seeds
}

\author{
Kifline Milebudi KIFUANI*, Anatole KIFUANI KIA MAYEKO, Bernard ILINGA \\ LOPAKA, Pitchou NGOY BOKOLOMBE, Tharcisse MONAMA ONDONGO, \\ Gracien EKOKO BAKAMBO et Jérémie MUSWEMA LUNGUYA
}
Laboratory of Physical Organic and Environmental Chemistry, Department of Chemistry, Faculty of Sciences, University of Kinshasa, P.O. Box 190, Kinshasa XI, Democratic Republic of the Congo.
* Corresponding author; E-mail: kifuanikifline@gmail.com ; Tel: (+243)89 5879602

\begin{abstract}
The aim objectives of present study were to prepare a bioadsorbent from the seeds of Cucumeropsis mannii Naudin (BCM) and to examine its effectiveness in the removal of methylene blue (MB) from aqueous solution by adsorption process. The process of adsorption of $\mathrm{MB}$ onto BCM was optimizing by varying different parameters such as contact time, initial dye concentration, and temperature. The kinetic of adsorption was analyzed using pseudo-first-order and pseudo-second-order kinetic models. The experimental equilibrium data were examined using Langmuir and Freundlich isotherms. Thermodynamics parameters were also determined. The results show that the maximum adsorption percentage is $89 \%$ and the maximum adsorption capacity is $47 \mathrm{mg} \mathrm{g}^{-1}$ at $308 \mathrm{~K}$. Isotherms studied showed that Freundlich model is the best model to describe adsorption of BCM onto MB. Kinetic studies show that the adsorption process follows pseudo second-orderkinetic model. The thermodynamic study indicated a negative value of $\Delta H^{\circ}\left(-41 \mathrm{~kJ} \mathrm{~mol}^{-1}\right)$ and shows that adsorption of $\mathrm{MB}$ on $\mathrm{BCM}$ is exothermic and essentially a chemical process. BCM is a potential bioadsorbent for the removal of $\mathrm{MB}$ from aqueous solution and can therefore be used for water purification process.
\end{abstract}

(C) 2018 International Formulae Group. All rights reserved.

Keywords: Cucumeropsis mannii Naudin, methylene blue, adsorption, bioadsorbent, isotherms, kinetics and thermodynamics.

\section{INTRODUCTION}

The use of organic dyes in many industrial activities such as dyeing of leather, paper, textiles, wood, silk, plastics, in cosmetic, food and pharmaceutical industries is the basis of many inconveniences (Alouani et al., 2018). The presence of organic dyes in effluents has many impacts on ecological receptor environment and on humans. Madhura et al. (2014) indicate that wastewater from processes using organic dyes has high biological oxygen demand (BOD) and chemical oxygen demand (COD). Other researchers (Maurya et al., 2008; Vanessa et al., 2017) report that organic dyes are the basis of several effects on human health. Some dyes are carcinogenic, mutagenic and teratogenic and are likely to cause several ailments such as nausea, hemorrhoids, skin and mucous ulcers, severe irritation of the respiratory system (Alouani et al., 2018). 
Almost $5 \%$ to $25 \%$ of dyes applied on tissues are not fixed, and thus found in wastewater and likely to pollute waters, aquatic species, including fauna and flora. Organic dyes are persistent pollutants. Therefore, the removal of organic dyes from waste effluents becomes environmentally very important.

Several techniques for removing dyes especially methylene blue from wastewater are used and include biological, chemical, and physicochemical methods such as precipitation, coagulation and floculation, membrane filtration, ion exchange, ozonation, irradiation and adsorption ( $\mathrm{Li}$ et al., 2009; Zidane et al., 2011 ; Sun et al., 2012; Kassale et al., 2015; Miyah et al., 2017; Oliveira et al., 2017). Most of these methods are costly, require a lot of energy, produce huge amounts of sludge or generate derivatives that are sometimes more toxic than the initial products themselves (Masson et al., 2015; Tchuifon et al., 2015). Of all these methods for water treatment, adsorption is proving to be the most. Activated carbon is one of the most used adsorbents on this subject (Kifuani et al., 2012; Sark et al., 2015; Maazou et al., 2017). However, the cost of producing activated carbon is quite often very high. Many scientists worldwide are working on the preparation of low costs adsorbent materials from cheap and locally available precursors, found in renewable natural sources, such as agro-industrial wastes (Laximi et al., 2010; Yao et al., 2015; Kifuani et al., 2018).

Methylene Blue is one of the most used dyes in the dyeing of several products, especially silk, cotton and wood, and for temporary coloring of papers. It is used as a colored redox indicator, histologic dye, or antiseptic for superficial wounds treatment (Atef et al., 2009). By contact, MB is likely to cause eye burns in humans or animals. Inhalation induces respiratory difficulties and oral ingestion causes nausea, vomiting, sweating and abundant cold sweats (Kifuani, 2013).

This manuscript is a continuation of the work done by Kifuani et al. (2018), from which they made a preliminary study of MB adsorption onto BCM in different conditions of $\mathrm{pH}$, time of contact, initial concentration and mass of adsorbent.

The aim objectives of present study were to prepare a bioadsorbent from seeds of Cucumeropsis mannii Naudin and to examine its effectiveness in the removal of MB from aqueous solution by adsorption. In this context, the effect of various parameters such as, contact time, initial dyes concentration and temperature on the adsorption efficiency of MB was evaluated. The adsorption kinetic was analyzed using the pseudo-first-order and pseudo-second-order kinetic models. The experimental equilibrium data were examined using Langmuir and Freundlich isotherms. Thermodynamics parameters were also determined.

\section{MATERIALS AND METHODS \\ Preparation and characterization of the bioadsorbent}

Bioadsorbent samples were prepared from seeds of Cucumeropsis mannii Naudin. The seeds were washed with tap water and then with distilled water. Washed, crushed and sieved barks (sieve with a mesh size $\leq 1$ $\mathrm{mm}$ ), the powder were dried at laboratory temperature and then in an oven (DEPATCH Oven Co) for $48 \mathrm{~h}$ at $45{ }^{\circ} \mathrm{C}$. The resulting powder was stored in an airtight container. The preliminary characterization of Cucumeropsis mannii Naudin biodsorbent (BCM) is presented in Table 1 .

\section{Preparation and analysis of dye solution}

Adsorption capacity was determined using methylene blue as organic dye model; a commercial product was used without purification. Methylene blue is the prototype of medium-sized dyes. Different solutions were prepared by successive dilutions with distilled water of initial solution $\left(1000 \mathrm{mg} \mathrm{L}^{-1}\right)$ to obtain $1 \mathrm{~L}$ of each of diluted solutions of concentrations ranging from $1 \mathrm{mg} \mathrm{L}^{-1}$ to 100 $\mathrm{mg} \mathrm{L}^{-1}$. These solutions were analyzed, before and after adsorption, by UV-Vis spectrophotometry (Spectrophotometer HACK, model 1115) at $\lambda_{\max }=662 \mathrm{~nm}$. The 
concentrations of the solutions were calculated using Beer-Lambert equation. The chemical structure of methylene blue is given in Figure 1.

\section{Batch adsorption tests}

The adsorption tests were carried out in discontinuous process, in hermetically sealed adsorber (LACOPE ADS X-3) containing 100 $\mathrm{mL}$ of $\mathrm{MB}$ solution $50 \mathrm{mg} \mathrm{L}^{-1}$ and $800 \mathrm{mg}$ of BCM bioadsorbent and the mixture was stirred gently with speed of $150 \mathrm{rpm}$ at different times ranging from $0 \mathrm{~min}$ to 450 min, different concentrations $\left(1 \mathrm{mg} \mathrm{L}^{-1}\right.$ to 100 $\left.\mathrm{mg} \mathrm{L}^{-1}\right)$ and different temperatures $(308 \mathrm{~K}$, $313 \mathrm{~K}, 318 \mathrm{~K}, 323 \mathrm{~K}$ and $328 \mathrm{~K}$ ) to examine the effect of various parameters such as, contact time, initial dyes concentration and temperature on the adsorption efficiency of MB. The stirring time was set at $180 \mathrm{~min}$, within the equilibrium field, for all experimental temperatures. After stirring, the suspension was centrifuged (centrifuge LABOFUGE 200 HERAEUS) at $3000 \mathrm{rpm}$ for 30 minutes. After centrifugation, the filtrates were analyzed at $662 \mathrm{~nm}$ using a HACK 1115 spectrophometer, and the adsorption capacity of BCM bioadsorbent was determined from the following equation (Kassale et al., 2015):

$$
Q_{e}=\frac{\left(C_{o}-C_{e}\right) \cdot V}{m_{B}}
$$

Where $Q_{e}$ is the adsorption capacity of bioadsorbant $\left(m g \mathrm{~g}^{-1}\right), \quad C_{o}$ the initial concentration of $\mathrm{MB}$ solution $\left(\mathrm{mg} \mathrm{L}^{-1}\right), V$ the solution volume (L), $C_{e}$ the equilibrium concentration of adsorbate $\left(\mathrm{mg} \mathrm{L}^{-1}\right)$ and $m_{B}$ the bioadsorbent mass.

The percentage of adsorption (\%Ads) of $\mathrm{MB}$ on the BCM bioadsorbent is given by the following equation (Saeed et al., 2010):

$$
\% A d s=\frac{C_{o}-C_{e}}{C_{o}} x 100
$$

Modeling the kinetic of the adsorption

The modeling of MB adsorption kinetics on BCM bioadsorbent was done using pseudo-first-order and pseudo-second-order kinetic models. The kinetic models commonly used for surface reaction are Lagergren pseudo-first-order and Lagergren pseudosecond-order. The equations usually used are as follows (Saeed et al., 2010):

Pseudo-first-order-Lagergren kinetic model:

$$
\begin{aligned}
& \frac{d q_{t}}{d t}=k_{1}\left(q_{e}-q_{t}\right) \\
& \ln \left(q_{e}-q_{t}\right)=\ln q_{e}-k_{1} t
\end{aligned}
$$

\section{Pseudo-second-order-Lagergren kinetic model:}

$$
\begin{aligned}
& \frac{d q_{t}}{d t}=k_{2}\left(q_{e}-q_{t}\right)^{2} \\
& \frac{1}{\left(q_{e}-q_{t}\right)}=\frac{1}{q_{e}}+k_{2} t
\end{aligned}
$$

In this study, the kinetic models were applied using kinetic equations developed by Kifuani et al.

Pseudo-first-order -Kifuani kinetic model (Kifuani et al., 2012):

$$
\ln \frac{q_{e}}{\left(q_{e}-q_{t}\right)}=k_{1} t \quad \text { [7] }
$$

Where $q_{\mathrm{e}}$ and $q_{\mathrm{t}}$ are adsorption capacity at equilibrium and at time $\mathrm{t}$, respectively ( $\mathrm{mg} \mathrm{g}^{-}$ $\left.{ }^{1}\right), k_{1}$ is the rate constant of pseudo-first-order adsorption $\left(\mathrm{min}^{-1}\right)$.

Pseudo-second-order- Kifuani kinetic model (Kifuani et al., 2012):

$$
\frac{q_{t}}{q_{e} \cdot\left(q_{e}-q_{t}\right)}=k_{2} t
$$

Where, $k_{2}$ is the rate constant of pseudosecond-order adsorption $\left(\mathrm{g} \mathrm{mg}^{-1} \mathrm{~min}^{-1}\right)$.

\section{Modeling the adsorption isotherms}

Modeling the adsorption isotherms was made using Langmuir and Freundlich equilibrium models. 


\section{The Langmuir model}

The Langmuir model (Alouani et al., 2018) has been used in its linear form given by the following equation:

$$
\frac{1}{Q_{e}}=\frac{1}{Q_{m}}+\frac{1}{Q_{m} \cdot K_{L}} \cdot \frac{1}{C_{e}}
$$

Where $Q_{e}$ is the amount of solute fixed per unit mass of adsorbent (apparent adsorption capacity) (mg $\left.\mathrm{g}^{-1}\right), \quad Q_{m}$ represents the maximum amount of solute fixed per unit of adsorbent mass $\left(\mathrm{mg} \mathrm{g}^{-1}\right), C_{\mathrm{e}}$ is the equilibrium concentration of the adsorbate $\left(\mathrm{mg} \mathrm{L}^{-1}\right)$ and $K_{\mathrm{L}}$, the Langmuir constant related to rate of adsorption.

The equilibrium parameter $\left(R_{\mathrm{L}}\right)$ is defined by the following equation (Alouani et al., 2018):

$$
R_{L}=\frac{1}{1+\mathrm{K}_{\mathrm{L}} \mathrm{C}_{\mathrm{o}}}
$$

Where $K_{\mathrm{L}}$ is the Langmuir constant $\left(\mathrm{L} \mathrm{mg}^{-1}\right)$ and $C_{\mathrm{o}}$, the initial dye concentration $\left(\mathrm{mg} \mathrm{L}^{-1}\right)$.

\section{The Freundlich model}

The linear equation of Freundlich (Miyah et al., 2017) is given by the following equation:

$\log Q_{e}=\log K_{F}+\frac{1}{n} \cdot \log C_{e}$
Where $Q_{e}$ is the amount adsorbed at equilibrium (mg $\left.\mathrm{L}^{-1}\right), \quad C_{e}$ the equilibrium concentration of adsorbate, $K_{F}$ the Freundlich constant, a constant related to the adsorption capacity; it is therefore the capacity of adsorption when equilibrium concentration is unitary. The dimensionless constant $n$ is related to the adsorption intensity.

\section{Thermodynamic parameters}

Adsorption tests were performed at five different temperatures: $308 \mathrm{~K}, 313 \mathrm{~K}, 318$ $\mathrm{K}, 323 \mathrm{~K}$, and $328 \mathrm{~K}$. The variation of the standard free enthalpy $\left(\Delta G^{\circ}\right)$ is calculated according to the equation ( $\mathrm{Li}$ et al., 2009):

$$
\Delta G^{o}=-R T \ln K_{L}
$$

Where $R$ is the gas constant $\left(\mathrm{J} \mathrm{mol}^{-1} \mathrm{~K}^{-1}\right), T$ is the absolute temperature $(\mathrm{K})$ and $K_{\mathrm{L}}$ is the Langmuir constant $\left(\mathrm{mg} \mathrm{L}^{-1}\right)$.

The variation standard enthalpy $\left(\Delta H^{\circ}\right)$ and the variation standard entropy $\left(\Delta S^{\circ}\right)$ were determined using Van't Hoff equation (Li et al., 2009):

$$
\operatorname{Ln} \mathrm{K}_{\mathrm{L}}=\left(\frac{\Delta \mathrm{S}^{\circ}}{\mathrm{R}}\right)-\left(\frac{\Delta \mathrm{H}^{\circ}}{\mathrm{R}}\right) \frac{1}{\mathrm{~T}}
$$

Table 1: Characteristics of the BCM bioadsorbent.

\begin{tabular}{lc}
\hline Parameters & Values \\
\hline Particle size & $\leq 1 \mathrm{~mm}$ \\
Humidity (\%) & 7.08 \\
Dry matter (\%) & 92.92 \\
$\mathrm{Ash}(\%)$ & 03.20 \\
$\mathrm{pH}_{\mathrm{ZPC}}$ & 05.02 \\
$\mathrm{~S}_{\mathrm{BM}}\left(\mathrm{m}^{2} \mathrm{~g}^{-1}\right)$ & 251.87 \\
\hline
\end{tabular}<smiles></smiles>

Figure 1: Chemical structure of Methylene Blue. 


\section{RESULTS}

\section{Characteristics of the bioadsorbent}

These characteristics are given in Table 1. It is observed that BCM has a high specific surface area $\left(251.87 \mathrm{~g} \mathrm{~cm}^{-3}\right)$. The $\mathrm{pH}_{\mathrm{PZC}}$ indicates that the surface of the bioadsorbent is zero at $\mathrm{pH}$ 5.02. Beyond this value, the surface of the bioadsorbent has a negative charged surface and below that $\mathrm{pH}$, the surface is positively charged. All experiments were conducted at auto-equilibrium $\mathrm{pH}$ (6.67).

\section{Effect of time on adsorption}

The effect of time on adsorption was studied by mixing a solution of BM $50 \mathrm{mg} \mathrm{L}^{-1}$ with $800 \mathrm{mg}$ of bioadsorbent. The adsorption time was varied from 0 min to $450 \mathrm{~min}$ and the temperature was varied from $308 \mathrm{~K}$ to 328 $\mathrm{K}$. The results obtained are presented in Figures 2 to 4 . The results of Figure 2 show a decrease in residual concentration with mixing time, and after a given time, the reduced concentration remains constant. The apparent adsorption capacity $\left(Q_{\mathrm{e}}\right)$ and the apparent adsorption percentage capacity (\%Ads) increase with the contact time BCM-MB at different temperatures, until a maximum value which remains constant despite the increase in time (Figures 3 and 4).This maximum value corresponds to maximum adsorption capacity or the maximum adsorption percentage (Table 2).

\section{Modeling of the adsorption kinetics}

Modeling of MB adsorption kinetics on BCM bioadsorbent was done using pseudofirst-order and pseudo-second-order kinetic models for surface reaction. The kinetic parameters of those models are given in Table 3.

\section{The adsorption isotherms of $\mathrm{MB}$}

The adsorption isotherms are shown in Figure 5. All isotherms are S-shaped with initial concavity facing downwards $(308 \mathrm{~K}$, $313 \mathrm{~K}$ and $323 \mathrm{~K}$ ) or upward ( $318 \mathrm{~K}$ and 328 $\mathrm{K})$.

\section{Modeling the Adsorption Isotherms}

Modeling the adsorption isotherms was made using the Langmuir and Freundlich models. The Langmuir and Freundlich parameters and the correlation coefficients are recorded in Table 4.

\section{Effect of adsorption temperature and thermodynamic parameters}

Adsorption tests were performed at five different temperatures $308 \mathrm{~K}, 313 \mathrm{~K}, 318$ $\mathrm{K}, 323 \mathrm{~K}$, and $328 \mathrm{~K}$. The results in Figures 6 and 7 show a decrease in the maximum adsorption capacity with increasing temperature. The variation in standard enthalpy $\left(\Delta H^{\circ}\right)$ and standard entropy $\left(\Delta S^{\circ}\right)$ were determined using Van't Hoff relationship, and results on the variations in the standard free energy $\left(\Delta G^{\circ}\right)$, standard enthalpy $\left(\Delta H^{\circ}\right)$, and standard entropy $\left(\Delta S^{\circ}\right)$ of the adsorption process are given in Table 5 .

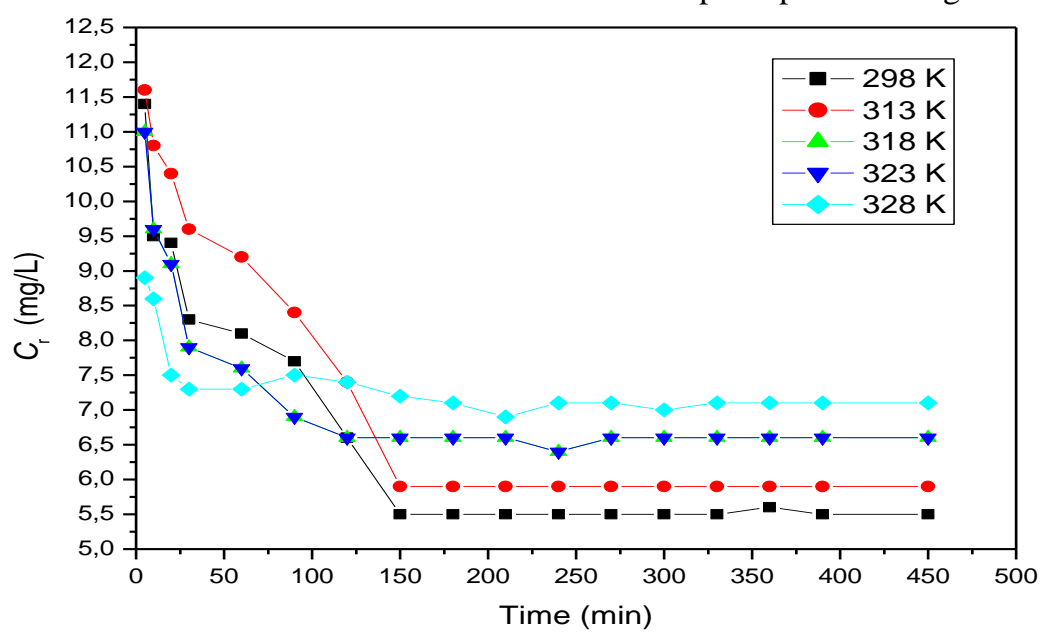

Figure 2: Residual concentration $\left(C_{\mathrm{r}}\right)$ vs. contact time at different temperatures. (pH: $6.67 ; m_{\text {всм }} 0.8 \mathrm{~g} ; V: 100 \mathrm{~mL}$ ). 


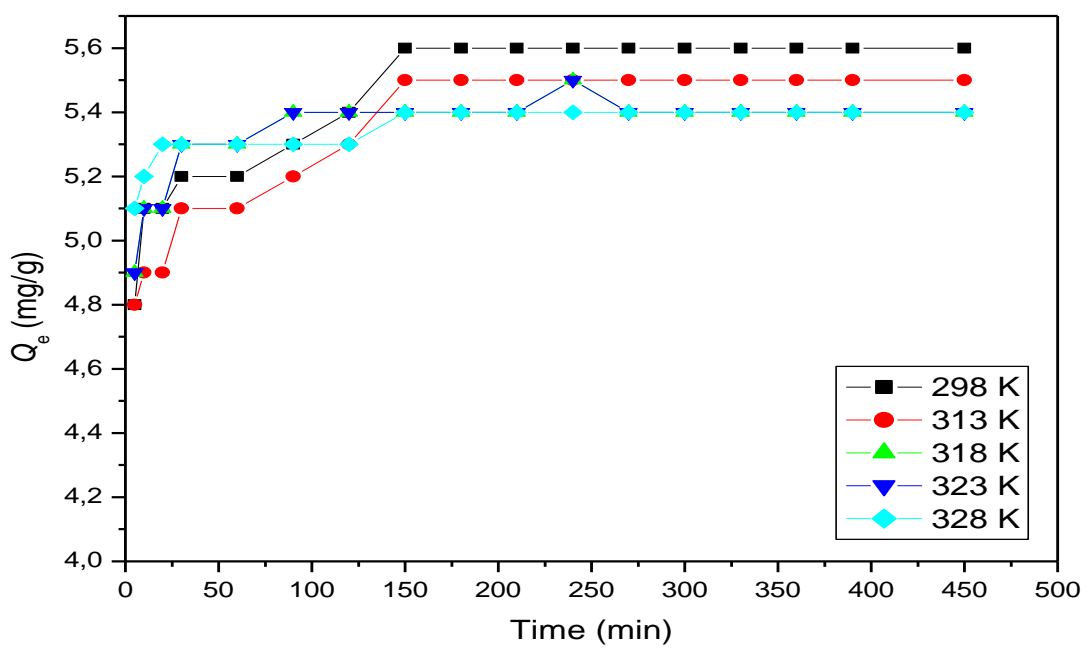

Figure 3: Effect of contact time on adsorption capacity of $\mathrm{BCM}\left(Q_{\mathrm{e}}\right)$ at different temperatures.

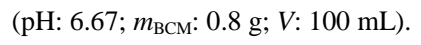

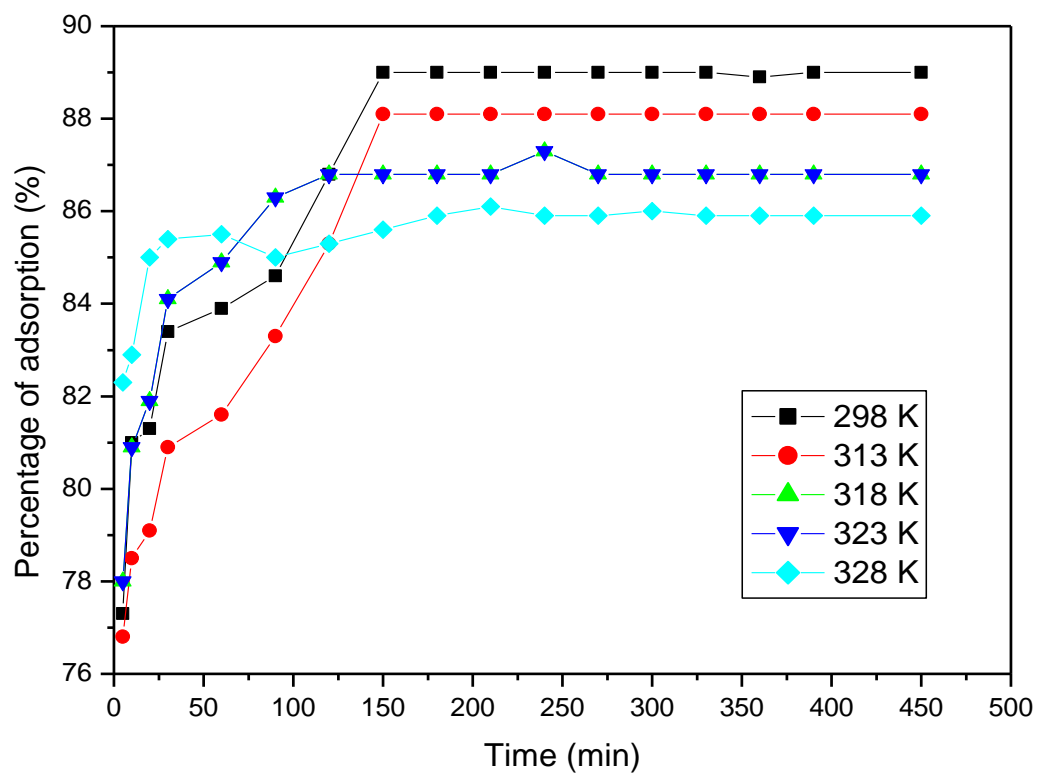

Figure 4: Effect of contact time on the percentage of $\mathrm{MB}$ adsorption on BCM at different temperatures. (pH: 6.67; $m_{\text {Всм: }}: 0.8 \mathrm{~g} ; \mathrm{V}: 100 \mathrm{~mL}$ ). 


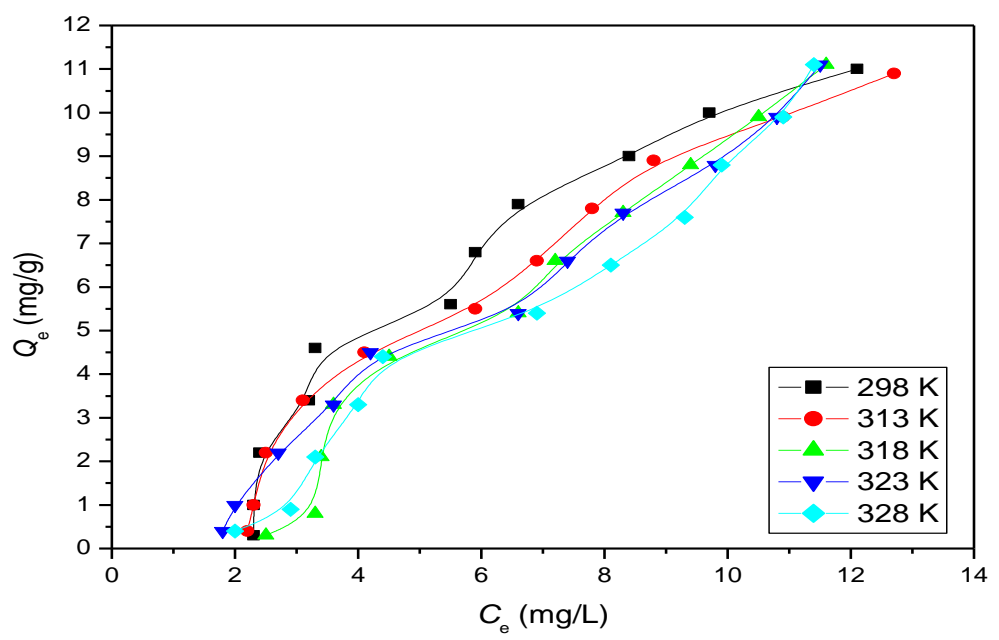

Figure 5: The adsorption isotherms of $\mathrm{MB}$ on the bioadsorbent $\mathrm{BCM}$ at different temperatures. (pH: 6.67; $m_{\text {ВСм }}: 0,8 \mathrm{~g} ; V: 100 \mathrm{~mL}$ ).

Table 2: Maximum adsorption capacity, percentage of adsorption and MB adsorption equilibrium time at different temperatures.

\begin{tabular}{lccc}
\hline Temperature (K) & $\boldsymbol{Q}_{\boldsymbol{m}}\left(\mathbf{m g ~ g}^{-\mathbf{1}}\right)$ & \% Ads & ET (min) \\
\hline 308 & 5.6 & 89.00 & 150 \\
313 & 5.5 & 88.13 & 150 \\
318 & 5.4 & 86.75 & 90 \\
323 & 5.4 & 86.75 & 90 \\
328 & 5.4 & 85.88 & 150 \\
\hline
\end{tabular}

ET: equilibrium time; $V: 100 \mathrm{~mL} ; C_{\mathrm{i}}: 50.0 \mathrm{mg} \mathrm{L}^{-1} ; \mathrm{pH}: 6.67$.

Table 3: Pseudo-first-order and pseudo-second-order parameters for the adsorption of MB onto $\mathrm{BCM}$ at different temperatures.

\begin{tabular}{lcccc}
\hline & \multicolumn{2}{c}{ Pseudo-first-order parameters } & Pseudo-second-order parameters \\
\cline { 2 - 5 } $\mathbf{T}(\mathbf{K})$ & $\boldsymbol{k}_{\mathbf{1}}\left(\mathbf{m i n}^{-1}\right)$ & $\mathbf{R}^{\mathbf{1}}$ & $\boldsymbol{k}_{\mathbf{2}}\left(\mathbf{g ~ m}^{-\mathbf{1}} \mathbf{~ m i n}^{-\mathbf{1}}\right)$ & $\mathbf{R}^{\mathbf{2}}$ \\
\hline 308 & 0.0077 & 0.9616 & 0.0228 & 0.8397 \\
313 & 0.0064 & 0.9690 & 0.0148 & 0.9468 \\
318 & 0.0030 & 0.9000 & 0.1595 & 0.9651 \\
323 & 0.0300 & 0.9000 & 0.1595 & 0.9651 \\
328 & 0.0084 & 0.3599 & 0.0663 & 0.3022
\end{tabular}

$V: 100 \mathrm{~mL} ; C_{\mathrm{i}}: 50.0 \mathrm{mg} \mathrm{L}{ }^{-1} ; \mathrm{pH}: 6.67$. 
Table 4: Langmuir and Freundlich parameters for the adsorption of MB onto BCM at different temperatures.

\begin{tabular}{cccccccc}
\hline $\mathbf{T}(\mathbf{K})$ & \multicolumn{2}{l}{ Langmuir parameters } & \multicolumn{4}{c}{ Freundlich parameters } \\
\cline { 2 - 7 } & $\boldsymbol{Q}_{\mathbf{m}}\left(\mathbf{m g ~ g}^{-1}\right)$ & $\boldsymbol{K}_{\mathbf{L}}\left(\mathbf{L} \mathbf{~ m g}^{-1}\right)$ & $\boldsymbol{R}_{\mathbf{L}}$ & $\mathbf{R}^{2}$ & $\boldsymbol{K}_{\mathbf{F}}{ }^{*}$ & $\mathbf{1} \boldsymbol{n}$ & $\mathbf{R}^{2}$ \\
\hline 308 & 47.9 & 0.026 & 0.4308 & 0.9136 & 1.1580 & 0.9549 & 0.9384 \\
313 & 46.1 & 0.025 & 0.4435 & 0.9907 & 1.0543 & 0.9512 & 0.9785 \\
318 & 44.3 & 0.029 & 0.4064 & 0.9600 & 0.8968 & 1.0173 & 0.9661 \\
323 & 70.6 & 0.015 & 0.5785 & 0.9558 & 0.8639 & 1.0276 & 0.9761 \\
328 & 237.5 & 0.004 & 0.8419 & 0.9055 & 0.8476 & 1.0077 & 0.9519 \\
\hline
\end{tabular}

$* \mathrm{~K}_{\mathrm{F}}$ unit: $\left(\mathrm{mg} \mathrm{g}^{-1}\right)\left(\mathrm{mg} \mathrm{L}^{-1}\right)^{-1 / n} ; V: 100 \mathrm{~mL} ; C_{\mathrm{i}}: 50.0 \mathrm{mg} \mathrm{L}^{-1} ; \mathrm{pH}: 6.67$.

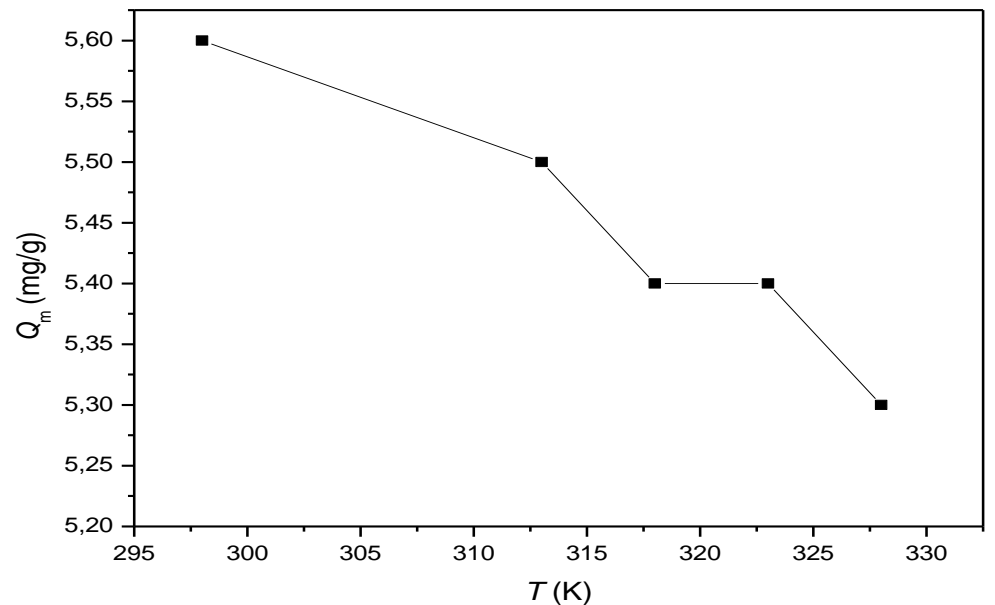

Figure 6: The maximum adsorption capacity $\left(Q_{\mathrm{m}}\right)$ vs. Temperature.

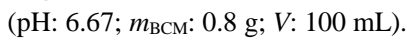

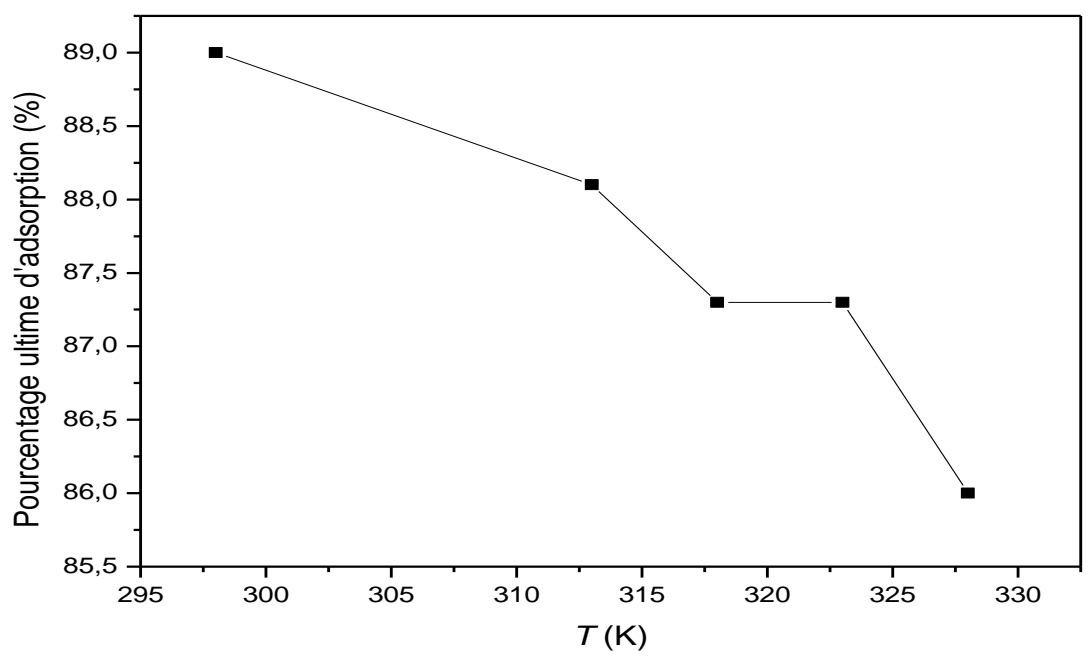

Figure 7: The maximum percentage of adsorption vs. Temperature. $\left(\mathrm{pH}: 6.67 ; m_{\text {ВСм: }} 0.8 \mathrm{~g} ; \mathrm{V}: 100 \mathrm{~mL}\right)$. 
Table 5: Thermodynamic parameters for the adsorption of $\mathrm{MB}$ onto $\mathrm{BCM}$ at different temperatures.

\begin{tabular}{|c|c|c|c|c|}
\hline$T(\mathbf{K})$ & $-\Delta S^{\circ}\left(\mathrm{J} \mathrm{mol}^{-1}\right)$ & $-\Delta \boldsymbol{H}^{\circ}\left(\mathbf{k J} \mathrm{mol}^{-1}\right)$ & $+\Delta G^{\circ}\left(\mathrm{kJ} \mathrm{mol}^{-1}\right)$ & $+\Delta G\left(\mathrm{~kJ} \mathrm{~mol}^{-1}\right)$ \\
\hline 298 & \multirow{6}{*}{381.03} & \multirow{6}{*}{110.83} & \multirow{6}{*}{2.72} & 2.72 \\
\hline 308 & & & & 6.53 \\
\hline 313 & & & & 8.44 \\
\hline 318 & & & & 10.34 \\
\hline 323 & & & & 12.24 \\
\hline 328 & & & & 14.15 \\
\hline
\end{tabular}

$V: 100 \mathrm{~mL} ; C_{\mathrm{i}}: 50.0 \mathrm{mg} \mathrm{L}^{-1} ; \mathrm{pH}: 6.67$.

\section{Effect of adsorption time}

The increase of adsorption percentage and adsorption capacity with time of contact (mixing time) BCM-MB is due to the availability of free adsorption sites on the surface of the bioadsorbent at the first contact. These sites are gradually saturated. The curves of Figures 3 and 4 show, at the beginning, a rapid increase in adsorption, which is due to the scattering (or external diffusion) of the particles of the adsorbate, characterized by the transfer of the solute through the film located on the geometric surface of the adsorbent. It is also observed a low growth in the percentage of adsorption over time, represented by the tangential part of each curve. This step characterizes an intraparticular diffusion of the matter in which the particles of the adsorbate are transferred through the outer and the inner surfaces of the bioadsorbent (Masson et al., 2015).

The plateau observed represents the surface reaction step, characterized by the fixation of the adsorbate particles on the inner surface at the active sites of micropores, because of the specific or non-specific interactions established between adsorbate particles and active sites of the bioadsorbent. The plateau indicates that the maximum removal rate of $89.00 \%$ was achieved at 308 $\mathrm{K}$ for $\mathrm{pH} 6.67$ (Table 2). The increase in adsorption capacity as a function of contact time is due to the availability of adsorption sites, as soon as adsorption begins. The resulting plateau indicates the saturation of the available adsorption sites. The maximum adsorption capacity of bioadsorbent $\left(Q_{\mathrm{m}}\right)$ is then achieved (Hameed et al., 2007).

\section{Adsorption isotherms}

The S-shaped isotherms indicate a multilayer adsorption (Ertaş et al., 2010; Kifuani, 2013). The initial downward-facing concavity (at $308 \mathrm{~K}, 313 \mathrm{~K}$ and $323 \mathrm{~K}$ ) suggests a cooperative adsorption in which the adsorbed molecules favor the fixation of other molecules that are still free at the heart of the solution. This downward-facing concavity also indicates that the solute molecules adsorb vertically to the surface of bioadsorbent. The initial upward-facing concavity (at $318 \mathrm{~K}$ and $328 \mathrm{~K}$ ) indicates the formation of multilayers of solute in solution at low concentrations. This type of isotherms reflects the existence of strong interactions between solute molecules, as compared to the interactions between solute molecules and adsorbent (Kifuani et al., 2013).

\section{Modeling of the adsorption kinetics}

The overall correlation coefficient (0.9327) obtained with pseudo-first-orderkinetic model is significantly higher than that obtained (0.9292) for pseudo-second-order kinetic model. This indicates that pseudo-firstorder kinetic model is more appropriate to describe adsorption of $\mathrm{MB}$ on $\mathrm{BCM}$ bioadsorbent (Vasanth et al., 2007). The correlation with pseudo-first-order model shows that adsorption is governed by the surface reaction, characterized by the binding of MB molecules to the surface of bioadsorbent. This correlation coefficient less 
than unity does not preclude other adsorption mechanisms.

\section{Modeling the adsorption isotherms}

The experimentally calculated values of Langmuir and Freundlich isotherm parameters are presented in Table 4. From the Table 4, it could be seen that Freundlich isotherm with a global correlation coefficient value, $R^{2}$, of 0.9622 is the most suited isotherm rather than Langmuir isotherm $\left(\mathrm{R}^{2}\right.$ : 9451) to describe the adsorption of MB dye onto BCM bioadsorbent. The correlation with Freundlich model implies formation of multilayer on bioadsorbent surface (Laximi Gayatri et al., 2010; Saeed et al., 2010; Alouani et al., 2018).

The $1 / n$ Freundlich parameter is related to the adsorption intensity, or to the strength of the adsorption interactions. It also indicates the relative distribution of energy sites for adsorption and depends on both nature and strength of the adsorption process (Sugana et al., 2010; Kifuani, 2013). It is reported that if the value of $1 / n$ is equal to 1 , the adsorption is linear. If it is greater than 1 , the adsorption is physical; and, if its value is less than 1, adsorption is a favorable chemical process. Values of $1 / n$ obtained are less than 1 (at $308 \mathrm{~K}$ and $313 \mathrm{~K}$ ), thus indicating that the adsorption of $\mathrm{MB}$ on the BCM is favorable and corresponds to a process of chemical adsorption. At higher temperatures the values of $1 / n$ are greater than 1 , suggesting an unfavorable adsorption at these temperatures. This corroborates the decrease in adsorption capacity observed with increasing temperature (Table 2).

The equilibrium parameter (or separation parameter), $R_{\mathrm{L}}$, represents the nature of adsorption phenomenon, which can be favorable $\left(0<R_{\mathrm{L}}<1\right)$, linear $\left(R_{\mathrm{L}}=1\right)$, unfavorable $\left(R_{\mathrm{L}}>1\right)$ or irreversible $\left(R_{\mathrm{L}}=0\right)$ (Kifuani et al., 2012). The values of $R_{\mathrm{L}}$ (Table 4) between 0 and 1 obtained in this work indicate that the adsorption is a favorable and a chemisorption process. The calculated maximum adsorption capacities (Table 4) indicate that BCM is a potential bioadsorbent for the removal of methylene blue from aqueous medium and can therefore be used for water purification treatment.

\section{Effect of adsorption temperature}

The decrease of the maximum percentage capacity and the maximum adsorption capacity with increasing temperature is explained by desorption of $\mathrm{BM}$ molecules with temperature due to the decrease in interactions between superficial functions of the bioadsorbant and those of the adsorbate (Alouani al., 2017). The increase in temperature increases the mobility of adsorbate molecules, resulting in a decrease in adsorption.

\section{Thermodynamic parameters}

The negative values of $\Delta H^{\circ}$, higher than $41 \mathrm{~kJ} \mathrm{~mol}^{-1}$ (Table 5) show that the adsorption of MB on BCM is exothermic and essentially a chemical process (Miyah et al., 2017). A negative value of entropy, $\Delta S^{\circ}$, indicate that the disorder of the molecules decrease in the interface between MB dye and BCM bioadsorbent. From Table 5, it could be seen that the standard free enthalpy have a positive value, which indicate a nonspontaneous adsorption process ( $\mathrm{Li}$ et al., 2009).

\section{Conclusion}

Adsorption of Methylene Blue onto $\mathrm{BCM}$ at five temperatures was investigated. Adsorption tests were carried out in discontinuous process. Results obtained in this work show that, at different temperatures, adsorption capacity and percentage of adsorption increase with time of adsorption until a maximum value which remains constant despite the increase in time. This increase is due to the availability of free adsorption sites at bioadsorbent surface at the first contact. All isotherms obtained in this study are S-shaped, with initial concavity facing downwards ( $308 \mathrm{~K}, 313 \mathrm{~K}$, and $323 \mathrm{~K}$ ) or upward $(318 \mathrm{~K}$ and $328 \mathrm{~K}$ ) and suggest a multilayered adsorption. The kinetic studies indicate that pseudo-first-order model is better indicated to describe adsorption of MB onto BCM. The negative value of standard enthalpy of adsorption, $\Delta H^{\circ}$, and its 
magnitude $\left(-41 \mathrm{~kJ} \mathrm{~mol}^{-1}\right)$ shows that the adsorption of $\mathrm{MB}$ on BCM is exothermic and essentially a chemical process. Therefore, the adsorption under study is more efficient at low temperatures. Values of $1 / n$ less than unity indicate that the adsorption of the $\mathrm{BM}$ on BCM is chemically favored at $308 \mathrm{~K}$ and 313 $\mathrm{K}$. The maximum adsorption capacities indicate that BCM is a potential bioadsorbent for the removal of methylene blue from aqueous environment and might be used as a water treatment technique.

\section{COMPETING INTERESTS}

The authors declare that they have no competing interests.

\section{CONTRIBUTIONS OF THE AUTHORS}

KMK. and AKKM are the main investigators of this study and have participated in all the stages of the research. BIL, GEB, TMO, JML and PNB have contributed to data processing and discussion of results.

\section{REFERENCES}

Alouani MEL, Alehyen S, Achouri MEL, Taibi M. 2018. Removal of cationic dyeMethylene Blue-from aqueous solution by adsorption on Fly Ash-based geopolymer. J. Mater. Environ. Sci., 9(1): 32-46. DOI: https://doi.org/10.26872/jmes.2018.9.1.5

Atef SA. 2009. Adsorption of methylene blue from aqueous solution onto a low-cost natural Jordan Tripoli. Amer. J. Environ. Sci., 5(3): 197-208. DOI 10.3844/ajessp.2009.197. 208

Ertaş M, Acemioğlu B, Hakki Alma M, Usta M. 2010. Removal of methylene blue from aqueous solution using cotton stalk, cotton waste and cotton dust. J. Hazard. Mater., 183(1-3): 421-427. DOI: 10.1016/ j.jhazmat.2010.07.041

Hameed BH, Ahmad AL, Latiff KNA. 2007. Adsorption of basic dye (methylene blue) onto activated carbon prepared from rattan sawdust. Dyes and Pigments, 75(1): 143-149. DOI: 10.1016/j.dyepig.2006.05.039
Kassale A, Barouni K, Bazzaoui M, Albourine A. 2015. Kinetics and Modeling of the adsorption of methylene blue by the grafted cotton. J. Chem. Bio. Phy. Sci., 5(2): 1205-1216. http://www.jcbpsc.org

Kifuani KM, Kifuani KMA, Noki VP, Ilinga LB, Ekoko BG, Mbala MB, Muswema LJ. 2018. Adsorption d'un colorant basique, Bleu de méthylène, en solution aqueuse sur un bioadsorbant issu de déchets agricoles de Cucumeropsis mannii Naudin. Int. J. Biol. Chem. Sci., 12(1): $558-575 . \quad$ DOI: https://dx.doi.org/10.4314/ijbcs.v12i1.43

Kifuani KMA, Noki VP, Ndelo DPJ, Mukana WMD, Ekoko BG, Ilinga LB, Mukinayi MJ. 2012. Adsorption de la quinine bichlorhydrate sur un charbon actif peu coûteux à base de la Bagasse de canne à sucre imprégnée de l'acide phosphorique. Int. J. Biol. Chem. Sci., 6(3): $\quad 1337-1359 . \quad$ DOI: 10.4314/ijbcs.v6i3.36

Kifuani KMA. 2013. Adsorption des composés organiques aromatiques sur charbon actif à base des déchets agroindustriels. Thèse de Doctorat, Université de Kinshasa, 265 p.

Kouakou YU, Dembele A, Ello AS, Brou YS, Yao BL, Trokourey A. 2015. Study of adsorption imidacloprid onto two different textures of soils. Int. J. Biol. Chem. Sci., 9(1): 472-482. DOI: htt//dx.doi.org/10.4314/ijbcs.v9i1.40

Laximi GS, Ahmazzaman MD. 2010. Adsorption technique for the removal of phenolic compounds from wastewater using low-cost natural adsorbents. Assam University Journal of Science and Technology, 5(2): 156-166.

Li K, Zheng Z, Huang X, Zhao G, Feng J, Zhang J. 2009. Equilibrium, kinetic and thermodynamic studies on the adsorption of 2-nitroaniline onto activated carbon prepared from cotton stalk fiber. $J$. Hazard Mater, 166(1): 213-220. DOI: 10.1016/j.jhazmat.-2008.11.007

Maazou SDB, Hima HI, Malam Alma MM, Adamou Z, Natatou I. 2017. Elimination du chrome par du charbon actif élaboré 
et caractérisé à partir de la coque du noyau de Balanites aegyptiaca. Int. J. Biol. Chem. Sci., 11(6): 3050-3065. DOI: https://dx.doi.org/10.4314/ijbcs.v11i6.39

Madhura C, Priyanka S, Charmi N, Sunil K, Sonali D. 2014. Removal of dye by adsorption on various adsorbents: A review. Inter. J. Sci. Eng. Technol. Res., 3(4): 835-840.

Masson S, Reinert, Guittonneau S, Duclaux L. 2015. Cinétiques et isothermes d'adsorption de micropolluants sur un tissu et un feutre de carbone activé. Revue des Sciences de l'Eau, 28(3): 207213. DOI : $10.7202 / 1034009$ ar

Maurya MS, Mittal AK, Correl P. 2008. Evaluation of adsorption potential of adsorbents: A case of uptake of cationic dyes. J. Environ. Biol., 29(1): 31-36. DOI: $\quad$ http://www.jeb.co.in/journal_issues/200801_jan08/paper_0 4.pdf

Miyah Y, Lahrichi A, Idrissi M, Anis Kh, Kachkoul R, Idrissi N, Lairini S, Nenov V, Zerrouq F. 2017. Removal of cationic dye «Cristal violet » in aqueous solution by the local clay. J. Mater. Environ. Sci., 8(10): 3570-3582. http://www.jmaterenvironsci.com

Oliveira P, Coufort-Saudejaud C, Alliet M, Frances C. 2017. Procédé de traitement des eaux usées par boues activées : lien entre les propriétés morphologiques des flocs et l'âge de boue. Revue des Sciences de l'Eau, 30(1): 29-32. DOI : 10.7202/1040060ar

Saeed A, Sharif M, Iqbal M. 2010. Application potential of grapefruit peel as dye sorbent: Kinetics, equilibrium and mechanism of crystal violet adsorption. J. Hazard. Mater., 179(1-3): 564-572. DOI : 10.1016/j.jhazmat.2010.03.041

Sakr F, Sennaoui A, Elouardi M, Tamimi M, Assabbane A. 2015. Etude de l'adsorption du Bleu de Méthylène sur un biomatériau à base de Cactus. $J$.
Mater. Environ. Sci., 6(2): 397-406. DOI:

Sugana M, Siva Kumar N, Venkata Subbaiah M, Krishnaiah. 2010. Removal of divalent manganese from aqueous solution using Tamarindus indica fruit nut Shell. J. Hazard. Mater, 2(1): 7-20.

Tchuifon Tchuifon DR, Nche G, Tchouanyo DH J, Ngakou SC, Djoumbissie AL, Anagho Solomon G, Kamgaing T, Ketcha JM. 2015. Adsorption studies of methylene blue on methanol modified and unmodified corn stalks and egussi peeling, Inter. J. Engin. Techn. Res.(IJETR), 3: 8-14.

Vanessa Peings V, Andrin A, Le Bechec M, Lacombe S, Frayret J, Pigot T. 2017. Couplage photocatalyse-oxydation par le ferrate (VI) pour le traitement du colorant rhodamine 6G. Revue des Sciences de l'Eau, 30(1): 35-39. DOI: 10.7202/1040061ar

Vasanth KK, Porkodi K. 2007. Mass transfer, kinetics and equilibrium studies for the biosorption of Methylene blue using Paspalum notatum. J. Hazard Mater., 146(2): 214-226. DOI: 10.1016/j.jhazmat.2006.12.010

Yao MK, Kouassi NL-K. 2015. Etude des propriétés d'adsorption et de désorption $\mathrm{du} \mathrm{Pb}$ et $\mathrm{Cd}$ par les sédiments d'une lagune tropicale en présence d'Allythiourée. Int. J. Biol. Chem. Sci., 9(1): $483-491 . \quad$ DOI: 10.4314/ijbcs.v9i1.41

Zidane F, Ohazzar A, Blais JF, Ayoubi K, Bensaid J, Basri SE, Kaba N, Fakhreddine Q, Lekheif B. 2011. Contribution à la dépollution des eaux usées de textile par électrocoagulation et par adsorption sur des composés à base du fer et d'aluminium. Int. J. Biol. Chem. Sci., 9(1): 1727-1745. DOI: 10.4314/ijbcs.v5i4.35 